\title{
Customary law and treaty
}

\author{
The Hon Justice Ralph Simmonds
}

\section{Introduction}

This paper, prepared for the conference and this volume, while I was the Chairman of the Law Reform Commission of Western Australia (the Commission), is intended to introduce the Commission and its Aboriginal Customary Law project, and also to indicate the stage that project has now reached, since the conference. I am most grateful to the Commission for its help to me in updating this text.

The Commission is an independent agency charged with providing advice to the Attorney General of WA. This advice takes the form of Final Reports, which the Attorney General (AG) would normally table in Parliament and thus make public. The Commission does this on matters referred to it by the AG. It provides the AG with advice in its Final Reports by way of critical examination of the area or areas of law touching the matter or matters referred to it. In the course of providing such advice the Commission may make any recommendations for reform of the law that it considers desirable.

The Commission has been doing all of this for over 30 years now, and has produced over 92 major reports. Fairly recently, at the AG's request, the Commission produced a review of that 30 year history, the 30th Anniversary Reform Implementation Report, ${ }^{1}$ to indicate what had become of its recommendations and what the government should do with any that remained unimplemented. This Report was well received, and the AG indicated that he would use it as the basis for changes to the law by legislation and otherwise over the coming years. He has in fact been doing just that, and most recently, in December 2004, a package of legislation to reform Western Australian civil and criminal procedure was enacted which implemented some 221 of the recommendations made in the Commission's epochal Review of the Criminal and Civil Justice System in Western Australia Final Report. ${ }^{2}$

I mention this history, because the Commission has played and continues to play an important role in public discussion of the law and in law reform in this State. It was thus a significant moment in the State's legal history when, in December 2000, the previous government's Attorney General gave the Commission what is currently its major reference, on 'Aboriginal customary law'. I put the term in quotation marks, because that is how the Commission received it. It is a reference that was adopted subsequently by the current Attorney General when he assumed office.

\footnotetext{
${ }^{1}$ Law Reform Commission of Western Australia 2002. $\quad{ }^{2}$ Law Reform Commission of Western Australia 1999.
} 


\section{The customary law project}

The terms of reference that the Commission received and that have been confirmed as I have indicated make it plain that what it was to examine was very broad indeed. It was to consider three principal matters:

1. how Aboriginal customary law is made, altered, recognised and applied;

2. who is bound by such law, and how they cease to be bound; and

3. whether such law should be recognised, and, if so, how it should be recognised, to what extent, and on what basis.

In relation to the third matter, the Commission was particularly asked to consider if certain law reform would be desirable. It was asked to consider whether the rest of the legal system of the State should, in its administration or enforcement, give express recognition to Aboriginal customary law. This was to include the administration and enforcement of state criminal and civil law. And it was also asked whether or not other provisions should be made for the identification and enforcement of Aboriginal customary law.

In relation to all three matters, the Commission was asked to consider the full range of matters of Aboriginal customary law that might fall within state legislative jurisdiction, although two matters were specifically left out. They were matters of native title and those arising under the Aboriginal Heritage Act 1972 (WA). This left a huge range, however, covering matters that the rest of the legal system would call matters of criminal law and of civil law. The Commission was also asked to consider Commonwealth legislation and Australia's international obligations, the last a particularly important matter. The Commission was further directed to consider two important matters (here I quote from the reference's Terms of Reference): ${ }^{3}$ first, relevant Aboriginal culture, spiritual, sacred and gender concerns and sensitivities; [and] second, the views, aspirations, and welfare of Aboriginal persons in Western Australia.

In undertaking this task, the Commission has drawn on the extraordinary work done by a similar body, at the federal level, in its report, The Recognition of Aboriginal Customary Law, published in 1986. ${ }^{4}$ This has been revisited in light of the many changes that have occurred since then, at the local, national and international levels. At the same time, the Commission has taken account of the fact that most of the federal body's (now the Australian Law Reform Commission) recommendations remain unimplemented after more than 15 years.

What has occurred since the end of 2000 in working on the project? Here it is appropriate to relate the project to the Conference theme: Treaty: Advancing Reconciliation.

It was evident to the Commission from the outset that it would be unable to produce a report that had the best chance of producing practical and valuable results of the sort the Indigenous community would wish without a form of partnership with them. Such a partnership would promote their input into the project, and assist the Commission in preparing a Final Report that would properly reflect their experience and views. The Commission would of course continue throughout to have responsibility for the production of the final report, in a form that, like the form of its other reports, would have the best chance of making a difference to Western Australians.

\footnotetext{
${ }^{3}$ See Appendix for complete Terms of Reference. $\quad{ }^{4}$ The Law Reform Commission (now the Australian Law Reform Commission) 1986.
} 
The Commission did considerable work on arrangements to make this sort of partnership possible. These arrangements are described in an article in the magazine of the Australian Law Reform Commission, Reform, written by three members of the Crime Research Centre at the University of Western Australia. ${ }^{5}$

As the article reports, the Commission, with the advice of representatives of the Indigenous community, appointed Ms Yavu-Kama-Harathuniam, a woman of the Cubbi Cubbi clan (North Queensland), as the full-time Project Manager, and she served the Project over its consultation phase. Dr Neil Morgan and Dr Harry Blagg of the Crime Research Centre were appointed as Research Directors of the Project. The Commission has also seen to it that two Special Commissioners for the project were appointed, in Mick Dodson and Beth Wood. In addition the Commission appointed a twelve-person Aboriginal Research Reference Council, with its membership drawn from across the Aboriginal community in this state, including, as the article explains, 'men and women elders, community representatives and relevant representatives of key Indigenous agencies and peak bodies ${ }^{6}{ }^{6}$ The Special Commissioners and the Council worked throughout the consultation phase of the project with the Project Manager and the Commission on the development and implementation of the strategy for undertaking the research and consultation in the Aboriginal community that the project required.

As the article explains, that research and consultation required the development of protocols and procedures to respect the sensitivities and concerns, while encouraging the participation of, the Aboriginal community. Out of this research and consultation, again as the article explains, was to come a series of background papers and other material on a range of topics within the terms of reference.

At the time of writing, the series of background papers numbered ten. By way of example, one is on court decisions in all Australian states and territories that had drawn on Aboriginal customary law in some way. Another is on the use of interpreters in court proceedings involving Aboriginal parties. Still another is on benchmarking frameworks to reduce Aboriginal disadvantage in the law and justice area. And there were, since the time of writing, five further background papers. All can be accessed from the Commission's website. ${ }^{7}$

The other material produced alongside the research papers principally comprises detailed notes of consultation visits with Aboriginal communities across Western Australia. There were over 20 individual visits, from Wuggubun in the north to Albany in the south. The notes of each such visit were in almost all cases sent back to representatives of the relevant community to permit further consultation to take place with them. This enabled the Commission to refine all of the consultation notes consistently with the protocols for respecting Aboriginal sensitivities and concerns so that the Commission could make the notes available to those interested in the Project. The Commission's website provides a map of Western Australia identifying the areas where consultation visits took place. By clicking on an area it is possible for the visitor to the site to read the consultation notes that were refined in that way.

In addition to the background papers and the other materials I have referred to, the Commission after the time of writing in December 2005, produced a Discussion Paper to bring together its tentative views and recommendations. This Discussion Paper is to stimulate further input

\footnotetext{
${ }^{5}$ Morgan et al 2002. $\quad 7$ Law Reform Commission of Western Australia at

${ }^{6}$ Morgan et al 2002: 12. http://www.lrc.justice.wa.gov.au/index.htm
} 
into the Project, particularly from Aboriginal communities. After there has been an opportunity for the Commission to consider that input, the Commission will produce its Final Report that will include the recommendations it will be making to the state government. That Final Report will be published after it has been tabled in the WA Parliament.

\section{Conclusion}

It is too early yet to know what recommendations the Final Report of the Commission is likely to contain. But I can at least refer to two ideas for change that one or more background papers addressed, and that the Commission is likely to address in its Final Report. The article in Reform to which I referred earlier mentions these ideas also. They are what are called in the article 'community justice mechanisms that assist in actively keeping the peace in Indigenous communities' and forms of 'restorative justice'. 8

More generally, in this Project, as the Terms of Reference appear to indicate, and as experience in the Project thus far confirms, there is likely throughout to be a particular concern with discussions of the processes of customary law, the processes in the rest of the legal system and the possible forms of accommodation between them, rather than an account in exhaustive detail of particular areas of customary law.

In other words, what the Commission's project on Aboriginal customary law is about is ways our legal system might better accommodate Aboriginal customary law. Such ways of accommodation I see to fall within the much broader forms of social accommodation and mutual exchange that the Conference for which these notes were prepared permitted all of us privileged to be at it to discuss and advance.

\section{References}

Law Reform Commission of Western Australia 1999, Review of the criminal and civil justice system in Western Australia Final Report (Project 92), The Commission, Perth, September.

- 2002, 3oth Anniversary Reform Implementation Report: Law Reform Commission of Western Australia 1972-2002, The Commission, Perth.

Morgan, N, H Blagg and C Yavu-Kama-Harathuniam 2002, 'Aboriginal customary law in Western Australia', Reform 80: 11.

The Law Reform Commission (now the Australian Law Reform Commission) 1986, Report No 31, The recognition of Aboriginal customary laws, AGPS, Canberra.

\section{Legislation}

Aboriginal Heritage Act 1972 (WA). 


\section{APPENDIX}

\section{Terms of Reference}

\section{Project 93 of the Law Reform Commission of Western Australia}

\section{'Aboriginal Customary Law'}

(December 2000)

Recognising that all persons in Western Australia are subject to and protected by this State's

legal system; and there may be a need to recognise the existence of, and take into account within

this legal system, Aboriginal customary laws:

The Law Reform Commission of Western Australia is to enquire into and report upon Aboriginal customary laws in Western Australia other than in relation to Native Title and matters addressed under the Aboriginal Heritage Act 1972 (WA).

Particular reference will be given to:

1. how those laws are ascertained, recognised, made, applied and altered in Western Australia;

2. who is bound by those laws and how they cease to be bound; and

3. whether those laws should be recognised and given effect to; and, if so, to what extent, in what manner and on what basis, and in particular whether:

a) the laws of Western Australia should give express recognition to Aboriginal customary laws, cultures and practices in the administration or enforcement of Western Australian law;

b) the practices and procedures of the Western Australian courts should be modified to recognise Aboriginal customary laws;

c) the laws of Western Australia relating to the enforcement of criminal or civil law should be amended to recognise Aboriginal customary laws; and

d) whether other provisions should be made for the identification and application of Aboriginal customary laws.

For the purposes of carrying out this inquiry, the Commission is to have regard to:

- matters of Aboriginal customary law falling within state legislative jurisdiction including

- matters performing the function of or corresponding to criminal law (including domestic violence);

- civil law (including personal property law, contractual arrangements and torts); 
The Hon Justice Ralph Simmonds

- local government law;

- the law of domestic relations;

- inheritance law;

- law relating to spiritual matters; and

- the laws of evidence and procedure;

- relevant Commonwealth legislation and international obligations;

176

- relevant Aboriginal culture, spiritual, sacred and gender concerns and sensitivities; [and]

- the views, aspirations and welfare of Aboriginal persons in Western Australia. 